\title{
Blood Pressure Changes on Tooth Extraction Using Local Anesthesia Contains 1:80,000 Epinephrine at Jatinangor Primary Health Care
}

\author{
Muhammad A Wijaya*, Marlianti Hidayat**, Trully D Sitorus*** \\ *Faculty of Medicine Padjadjaran University \\ ** Department of Dentistry Faculty of Medicine Padjadjaran University \\ *** Department of Pharmacology Faculty of Medicine Padjadjaran University \\ Jl. Prof. Eyckman No. 38 Bandung 40161 Indonesia \\ Email: muhammad.almamaepu@gmail.com
}

\begin{abstract}
Hypertension is a systemic disorder with one of the highest prevalences in the world, particularly in Indonesia. Problem arises in hypertension patients when administration of local anesthetic containing epinephrine 1:80.000 is indicated to be given before undergoing tooth extraction procedure in primary health care setting. This procedure can cause sudden blood pressure to increase. This study aims to observe the increase of blood pressure after local anesthesia exposure that contains epinephrine 1:80.000. This is a descriptive quantitative study conducted from April to August 2017 in Puskesmas Jatinangor. Blood pressure data is acquired from normotension and prehypertension patients aged 18-50 years who undergo tooth extraction procedure. Blood pressure is measured before and after local anesthesia exposure. The result shows that there is an increase in the mean systolic blood pressure as much as 3.43 $\mathrm{mmHg}$. The increase in systolic blood pressure occurs from the effect of epinephrine that causes constriction of the blood vessels. It is concluded that administration of local anesthetic containing epinephrine 1:80.000 before tooth extraction procedure is relatively safe and can be considered to be used in pre-hypertension patients, but not in higher hypertension stages.
\end{abstract}

Keywords: blood pressure, epinephrine, hypertension, local anesthetic, tooth extraction 


\title{
Perubahan Tekanan Darah pada Tindakan Pencabutan Gigi Menggunakan Anestesi Lokal Mengandung Epinefrin 1:80.000 di Puskesmas Jatinangor
}

\author{
Muhammad A Wijaya*, Marlianti Hidayat**, Trully D Sitorus*** \\ *Fakultas Kedokteran Universitas Padjadjaran \\ **Departemen Gigi dan Mulut Fakultas Kedokteran Universitas Padjadjaran \\ ****Departemen Farmakologi Fakultas Kedokteran Universitas Padjadjaran \\ J1. Prof. Eyckman No. 38 Bandung 40161 Indonesia \\ Email: muhammad.almamaepu@gmail.com
}

\begin{abstract}
Abstrak
Hipertensi hingga saat ini merupakan salah satu penyakit sistemik dengan prevalensi tertinggi di dunia, terutama di Indonesia. Salah satu masalah yang sering dihadapi oleh para penderita hipertensi adalah tindakan pemberian anestesi lokal mengandung epinefrin 1:80.000 yang harus dilakukan sebelum menjalani tindakan pencabutan gigi di puskesmas. Tindakan pemberian anestesi ini berisiko karena dapat menyebabkan peningkatan tekanan darah secara tiba-tiba yang mungkin menyebabkan terjadinya komplikasi. Penelitian ini bertujuan untuk melihat berapa besar peningkatan tekanan darah yang terjadi setelah pemberian anestesi lokal mengandung epinefrin 1:80.000. Penelitian ini merupakan penelitian deskriptif kuantitatif yang dilaksanakan pada April-Agustus 2017 di Puskesmas Jatinangor. Data tekanan darah merupakan data primer, didapat dari pasien dengan normotensi dan prehipertensi berusia 18-50 tahun yang menjalani tindakan pencabutan gigi. Tekanan darah diukur sebelum dan sesudah diberi anestesi lokal. Hasil menunjukan terdapat peningkatan rerata tekanan darah sistolik sebesar $3.43 \mathrm{mmHg}$. Peningkatan tekanan darah sistolik terjadi karena efek dari epinefrin yang menyebabkan vasokonstriksi pembuluh darah. Disimpulkan bahwa pemberian anestesi lokal dengan epinefrin 1:80.000 sebelum tindakan pencabutan gigi tergolong cukup aman dan dapat dipertimbangkan untuk digunakan pada pasien prehipertensi namun tidak dianjurkan untuk diberikan kepada pasien dengan derajat hipertensi yang lebih tinggi.
\end{abstract}

Kata kunci: tekanan darah, epinefrin, hipertensi, anestesi lokal, pencabutan gigi 


\section{Research Article}

\section{Pendahuluan}

Hipertensi atau tekanan darah tinggi hingga saat ini masih merupakan salah satu penyakit sistemik dengan prevalensi tertinggi di dunia, ${ }^{1,2}$ dengan prevalensi di Indonesia pada masyarakat dengan usia $\geq 18$ tahun berdasarkan Riset Kesehatan Dasar (Riskesdas) Kementerian Kesehatan Republik Indonesia pada tahun 2013 sebesar 25,8 persen dan khusus di Provinsi Jawa Barat sebesar 29,4 persen. $^{3}$ Menurut World Health Organization (WHO), hipertensi didefinisikan sebagai tekanan darah sistolik $\geq 140 \mathrm{mmHg}$ dan/atau tekanan darah diastolik $\geq 90$ mmHg. ${ }^{4}$ Seorang pasien dinyatakan memiliki hipertensi apabila rata-rata dari dua kali atau lebih hasil pemeriksaan tekanan darah pada setiap kunjungan ke fasilitas kesehatan dengan minimal dua kali kunjungan memenuhi kriteria hipertensi. ${ }^{5,6}$ Salah satu masalah utama yang dihadapi para penderita hipertensi adalah saat perlu dilakukan tindakan pencabutan gigi dengan menggunakan anestesi lokal yang mengandung agen vasokonstriktor yang dapat menyebabkan peningkatan tekanan darah secara tiba-tiba dan dapat menimbulkan komplikasi mengancam nyawa. ${ }^{5}$ Penggunaan agen vasokonstriktor pada anestesi lokal bertujuan untuk menetralkan efek vasodilatasi dari agen anestesi lokal dan menghambat absorpsi agen anestesi ke sistem kardiovaskular. Efek ini berguna dalam meningkatkan durasi anestesi lokal, meminimalisir resiko efek samping, dan menjaga hemostasis selama operasi. ${ }^{7,8}$

Saat ini agen vasokonstriktor utama yang digunakan dalam praktik kedokteran gigi adalah epinefrin. ${ }^{5}$ Pada dosis rendah epinefrin hanya bekerja pada reseptor $\beta$ adrenergik yang menghasilkan efek berupa peningkatan denyut jantung dan kekuatan kontraksi jantung, sedangkan dengan dosis yang lebih tinggi epinefrin juga bekerja pada reseptor $\alpha$ adrenergik di pembuluh darah perifer yang menyebabkan vasokonstriksi pembuluh darah sehingga pada akhirnya dapat menyebabkan peningkatan tekanan darah. ${ }^{7}$ Oleh karena itu, penggunaan epinefrin pada anestesi lokal untuk tindakan pencabutan gigi pada pasien penderita hipertensi hingga saat ini masih tergolong berisiko dan dapat meningkatkan angka morbiditas dan mortalitas penderita hipertensi. ${ }^{1,5,9}$

Pada penelitian sebelumnya oleh Bader pada tahun 2002 dan Gungormus pada tahun 2003 terkait keamanan penggunaan anestesi lokal dengan epinefrin pada pasien hipertensi, didapatkan bahwa penggunaan dua cartridge lignocaine $1,8 \mathrm{ml}$ yang mengandung epinefrin 1:100.000 $(0,036 \mathrm{mg})$ tergolong aman pada pasien hipertensi yang terkontrol dan pasien dengan derajat 1 hipertensi. ${ }^{1}$ Namun di Indonesia, sediaan anestesi lokal yang tersedia di rumah sakit dan puskesmas pada umumnya mengandung epinefrin 1:80.000 atau tidak mengandung epinefrin sama sekali sehingga apabila ingin menggunakan anestesi lokal yang mengandung epinefrin 1:100.000 harus dilakukan pengenceran terlebih dahulu dari sediaan yang tersedia 


\section{Research Article}

secara manual. Proses pengenceran yang dilakukan secara manual ini tentu diragukan keakuratannya, tidak terjamin kualitasnya, dan secara tidak langsung dapat membahayakan keselamatan pasien. Di sisi lain, penggunaan obat anestesi lokal tanpa epinefrin dapat menyebabkan durasi kerja obat anestesi yang lebih singkat dan tidak terkontrolnya pendarahan yang akan menyulitkan proses operasi. ${ }^{10}$ Namun penggunaan anestesi lokal yang mengandung epinefrin 1:80.000 pada pasien hipertensi masih belum terjamin keamanannya karena kurang memadainya literatur yang tersedia baik dari segi kualitas maupun kuantitas yang membuktikan keamanan penggunaannya, terutama di Indonesia.

Penelitian ini dilakukan dengan tujuan untuk mengetahui berapa besar perubahan tekanan darah yang terjadi pada tindakan pencabutan gigi menggunakan anestesi lokal mengandung epinefrin 1:80.000 pada masyarakat di Indonesia, khususnya di wilayah Jatinangor, Jawa Barat.

\section{Metode}

Penelitian ini merupakan penelitian deskriptif kuantitatif dengan desain penelitian potong lintang yang dilakukan dari bulan April hingga Agustus 2017 di Puskesmas Jatinangor. Subjek penelitian adalah seluruh masyarakat yang tinggal di daerah Jatinangor dan sekitarnya yang menjalani tindakan pencabutan gigi di Puskesmas Kecamatan Jatinangor dengan kriteria inklusi berupa usia 18-50 tahun, pernah menjalani tindakan pencabutan gigi minimal satu kali, memiliki normotensi atau tergolong prehipertensi (tekanan darah sistolik 120-139 mmHg, tekanan darah diastolik $80-89 \mathrm{mmHg}$ ), akan menjalani tindakan pencabutan gigi dengan pemberian anestesi lokal, dan bersedia mengikuti penelitian ini dengan mengisi lembar informed consent. Adapun kriteria eksklusi dari penelitian ini adalah subjek yang menjalani tindakan pencabutan gigi tanpa menggunakan anestesi lokal yang mengandung epinefrin 1:80.000, memiliki penyakit sistemik atau kelainan jiwa, dan sedang dalam masa pengobatan atau mengonsumsi obat-obatan lainnya.

Data tekanan darah didapat dengan cara mengukur tekanan darah subjek sebanyak dua kali menggunakan tensimeter digital di lengan kanan subjek sesaat sebelum diberi anestesi lokal dan 3-5 menit setelah diberi anestesi lokal dengan sebelumnya subjek sudah dipastikan dalam kondisi tenang. Tindakan pengukuran tekanan darah dilakukan sebelum pasien menjalani tindakan pencabutan gigi dan dilakukan dengan izin dokter gigi yang melakukan tindakan pencabutan gigi. Instrumen penelitian yang digunakan berupa tensimeter digital dan alat pengukur waktu. Penelitian ini telah mendapat persetujuan dari Komisi Etik Penelitian Kesehatan Fakultas Kedokteran Universitas Padjadjaran, SK no. 483/UN6.C.10/PN/2017 tahun 
2017, Badan Perencanaan Pembangunan Penelitian dan Pengembangan Daerah (BAPPPPEDA) Kabupaten Sumedang SK no. 070/316-PPEP/Bapppp/2017, dan Dinas Kesehatan Kabupaten Sumedang surat izin no. 070/063/SDK/IV/2017. Data yang didapatkan dalam penelitian ini merupakan data numerik yang bersifat kuantitatif. Data tekanan darah diuji normalitas (ShapiroWilk) dan diolah secara deskriptif numerik dalam bentuk rerata dan simpang baku.

\section{Hasil}

Jumlah sampel yang didapatkan pada penelitian ini yaitu sebanyak 30 pasien. Karakteristik sampel pasien pada penelitian ini berdasarkan usia, jenis kelamin, dan tekanan darah sistolik dan diastolik sebelum diberi anestesi lokal mengandung epinefrin 1:80.000 dapat dilihat pada tabel 1, 2 dan gambar 1.

Tabel 1 Data Statistik Usia Pasien

\begin{tabular}{cc}
\hline & Usia (tahun) \\
\hline Rerata $(\mathrm{sb})$ & $35,20(9,26)$ \\
Median & 37 \\
Modus & 44 \\
Range & $18-47$ \\
\hline
\end{tabular}

Tabel 2 Distribusi Karakteristik Pasien berdasarkan Jenis Kelamin dan Tekanan Darah Sistolik dan Diastolik Sebelum Diberi Anestesi Lokal mengandung Epinefrin 1:80.000

\begin{tabular}{lc}
\hline \multicolumn{1}{c}{ Karakteristik } & Frekuensi \\
\hline Jumlah Sampel Penelitian & 30 \\
Jenis Kelamin & \\
$\quad$ Laki-laki & 12 \\
$\quad$ Perempuan & 18 \\
Tekanan Darah Sistolik & \\
$\quad \begin{array}{l}120-139 \mathrm{mmHg} \\
<120 \mathrm{mmHg}\end{array}$ & 14 \\
Tekanan Darah Diastolik & 16 \\
$80-89 \mathrm{mmHg}$ & 15 \\
$<80 \mathrm{mmHg}$ & 15 \\
\hline
\end{tabular}




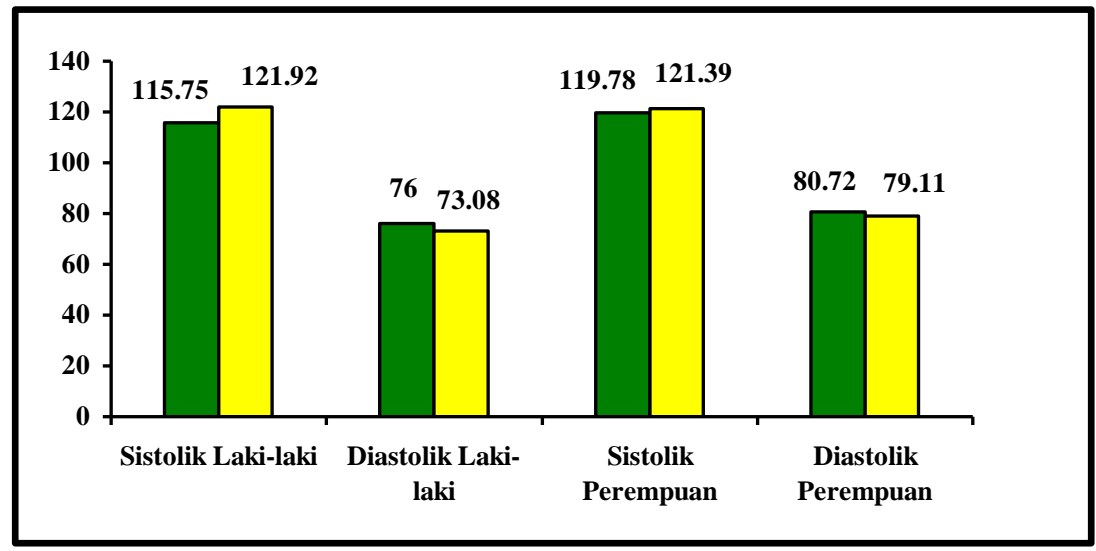

\section{Gambar 1 Sistolik/Diastolik Laki-laki dan Perempuan Sebelum dan Sesudah Pemberian Anestesi Lokal mengandung Epinefrin 1:80.000}

Keterangan:

Satuan dalam $\mathrm{mmHg}$.

Hijau: Waktu pengukuran tekanan darah pertama (sebelum diberi anestesi lokal).

Kuning: Waktu pengukuran tekanan darah kedua (3-5 menit setelah diberi anestesi lokal). ${ }^{11}$

Dari gambar 1 tersebut didapatkan bahwa rerata tekanan darah sistolik sebelum dan setelah diberi anestesi lokal secara berturut-turut adalah sebesar 115,75 $\mathrm{mmHg}$ dan 121,92 mmHg untuk pasien laki-laki dan 119,78 $\mathrm{mmHg}$ dan $121,39 \mathrm{mmHg}$ untuk pasien perempuan. Rerata tekanan darah diastolik sebelum dan setelah diberi anestesi lokal secara berturut-turut adalah sebesar $76 \mathrm{mmHg}$ dan $73,08 \mathrm{mmHg}$ untuk pasien laki-laki dan $80,72 \mathrm{mmHg}$ dan 79,11 mmHg untuk pasien perempuan.

Tabel 2 Rerata Perubahan Tekanan Darah

\begin{tabular}{cccc}
\hline Jenis Kelamin & T1 (s.b.) & T2 (s.b.) & $\Delta$ T (s.b.) \\
\hline Laki-laki & & & \\
Sistol & $115,75(14,716)$ & $121,92(12,838)$ & $6,17(6,644)$ \\
Diastol & $76,00(9,677)$ & $73,08(8,618)$ & $-2,92(4,231)$ \\
Perempuan & & & \\
Sistol & $119,78(11,337)$ & $121,39(13,565)$ & $1,61(8,534)$ \\
Diastol & $80,72(6,497)$ & $79,11(8,373)$ & $-1,61(6,774)$ \\
\hline Keterangan: & &
\end{tabular}

\section{Keterangan:}

Satuan dalam mmHg.

T1: Waktu pengukuran tekanan darah pertama (sebelum diberi anestesi lokal).

T2: Waktu pengukuran tekanan darah kedua (3-5 menit setelah diberi anestesi lokal). ${ }^{11}$

$\Delta \mathrm{T}$ : Selisih tekanan darah waktu kedua dan pertama (T2-T1)

S.b.: Simpangan baku

Pada tabel 2 dapat dilihat bahwa rerata tekanan darah sistolik pada pasien laki-laki mengalami peningkatan sebesar $6,17 \mathrm{mmHg}$ dengan simpang baku sebesar $\pm 6,644 \mathrm{mmHg}$ dan pada pasien perempuan terjadi peningkatan rerata tekanan darah sistolik sebesar $1,61 \mathrm{mmHg}$ dengan simpang baku sebesar $\pm 4,231 \mathrm{mmHg}$. Untuk rerata tekanan darah diastolik pada pasien 


\section{Research Article}

laki-laki maupun perempuan tidak mengalami peningkatan, namun mengalami penurunan secara berturut-turut sebesar 2,92 $\mathrm{mmHg}$ dan $1,61 \mathrm{mmHg}$.

\section{Diskusi}

Dalam penelitian ini, didapatkan bahwa terjadi peningkatan rerata tekanan darah sistolik dan penurunan rerata tekanan darah diastolik pada pasien laki-laki dan perempuan setelah dilakukannya pemberian anestesi lokal yang mengandung epinefrin 1:80.000 sebelum tindakan pencabutan gigi. Peningkatan rerata tekanan darah sistolik setelah tindakan anestesi pada pasien laki-laki dan perempuan secara keseluruhan sebesar 3,43 mmH. Hasil ini sesuai dengan penelitian yang dilakukan oleh Nedal yang mendapatkan peningkatan rerata tekanan darah sistolik 3 menit setelah tindakan anestesi lokal dengan lidokain 2 persen sebesar 5,88 mmHg. ${ }^{7}$ Peningkatan tekanan darah ini terjadi sebagai efek vasokonstriksi yang terjadi karena kerja epinefrin pada anestesi lokal yang merangsang reseptor $\alpha 1$ adrenergik di pembuluh darah perifer. Selain itu stimulasi pada reseptor $\beta 1$ adrenergik di jantung oleh epinefrin juga menyebabkan peningkatan denyut jantung dan kekuatan kontraksi jantung sehingga secara keseluruhan menyebabkan peningkatan tekanan darah. ${ }^{7,10,12,13}$ Perbedaan peningkatan tekanan darah dengan penelitian sebelumnya secara individu dapat disebabkan oleh beberapa faktor anatara lain pasien sudah sering/pernah menjalani tindakan pencabutan gigi sebelumnya dan rasa aman dan nyaman pasien terhadap operator. Hal ini disebabkan karena apabila pasien belum pernah dicabut gigi sebelumnya dan operator tidak memberikan rasa aman dan nyaman kepada pasien akan menyebabkan kondisi stres psikologis pada pasien karena rasa takut yang kemudian dapat menyebabkan pelepasan katekolamin (epinefrin) endogen yang menyebabkan peningkatan denyut jantung dan tekanan darah. ${ }^{14}$

Rerata tekanan darah diastolik pada pasien laki-laki dan perempuan secara umum menunjukkan hasil sebaliknya yaitu bukan mengalami peningkatan, namun mengalami penurunan sebesar 2,13 mmHg. Hasil ini juga sesuai dengan penelitian yang dilakukan oleh Nedal yang mendapatkan penurunan rerata tekanan darah diastolik sebesar 3,03 $\mathrm{mmHg}$. Penurunan tekanan darah diastolik salah satu faktornya disebabkan oleh stimulasi reseptor $\beta 2$ adrenergik oleh epinefrin yang menyebabkan vasodilatasi dari pembuluh darah pada otot rangka. ${ }^{7,10}$ Pada dosis dan konsentrasi yang rendah (1:100.000), epinefrin hanya menyebabkan vasokonstriksi secara lokal pada pembuluh darah kecil di jaringan submukosa tempat epinefrin diinjeksikan. Hal ini terjadi karena pada pembuluh darah ini hanya terdapat reseptor $\alpha$ adrenergic, sedangkan pada pembuluh darah sistemik yang lebih besar terdapat lebih banyak reseptor $\beta 2$ adrenergik dibandingkan reseptor $\alpha$ sehingga dosis kecil epinefrin akan 


\section{Research Article}

menyebabkan vasodilatasi yang menyebabkan menurunnya tekanan darah diastolik. Di saat yang bersamaan, hasil penelitian sebelumnya oleh Chaudry menunjukkan bahwa walaupun pada konsentrasi dan dosis yang rendah epinefrin dapat merangsang reseptor $\beta 1$ agrenergik di sel-sel jantung yang menybabkan peningkatan denyut dan curah jantung sehingga menyebabkan terjadinya peningkatan tekanan darah sistolik yang bersamaan dengan menurunnya tekanan darah diastolik. ${ }^{1,11}$

Berdasarkan hasil penelitian ini, pemberian anestesi lokal yang mengandung epinefrin 1:80.000 sebelum tindakan pencabutan gigi menyebabkan peningkatan tekanan darah sistolik yang tidak signifikan secara klinis. Oleh karena itu, penggunaan anestesi lokal dengan epinefrin 1:80.000 sebelum tindakan pencabutan gigi pada pasien prehipertensi masih tergolong cukup aman.

Keterbatasan penelitian ini adalah jumlah sampel yang berjumlah sedikit yaitu sebesar 30 sampel. Hal tersebut dikarenakan waktu penelitian terbatas dan bersinggungan dengan Bulan Ramadhan yang menyebabkan berkurangnya pasien yang menjalani tindakan pencabutan gigi di Puskesmas Jatinangor. Penyebab lain terbatasnya waktu pengambilan data (April-Agustus 2017) dan terbatasnya jumlah pasien yang memenuhi kriteria inklusi dan eksklusi yang sudah ditentukan, karena mayoritas pasien yang menjalani tindakan pencabutan gigi di Puskesmas Jatinangor adalah anak-anak dan lanjut usia (lansia).

\section{Simpulan}

Pemberian anestesi lokal yang mengandung epinefrin 1:80.000 sebelum tindakan pencabutan gigi menyebabkan peningkatan tekanan darah sistolik yang cukup aman untuk diberikan kepada pasien prehipertensi. Penggunaannya untuk pasien dengan derajat hipertensi yang lebih tinggi belum diteliti sehingga tidak disarankan penggunaannya karena memiliki risiko yang jauh lebih tinggi. Disarankan penelitian selanjutnya menggunakan sampel dengan jumlah yang lebih besar dan kelompok populasi yang lebih bervariasi agar didapatkan hasil yang lebih akurat.

\section{Daftar Pustaka}

1. Chaudhry S, Iqbal HA, Izhar F, Mirza KM. Effect on blood pressure and pulse rate after administration of an epinephrine containing dental local anaesthetic in hypertensive patients. JPMA-Journal Pakistan Med Assoc. 2011;61(11):1088.

2. World Health Organization. Blood pressure prevalence [Internet]. 2014 [cited 2016 Oct 22]. Available from: http://www.who.int/gho/ncd/risk_factors/blood_pressure_prevalence/en/.

3. Badan Penelitian dan Pengembangan Kesehatan Kemeterian Kesehatan RI. Riset Kesehatan dasar. 2013. Laporan nasional 2013;1-268.

4. World Health Organization. Hypertension [Internet]. 2015 [cited 2016 Oct 15]. Available from: http://www.who.int/features/qa/82/en/. 


\section{Research Article}

5. Abu-mostafa N, Aldawssary A, Assari A, Alnujaidy S, Almutlaq A. A prospective randomized clinical trial compared the effect of various types of local anesthetics cartridges on hypertensive patients during dental extraction. J Clin Exp Dent. 2015;7(1):e84.

6. Piepoli MF, Hoes A, Agewall S. European Guidelines on cardiovascular disease prevention in clinical practice: The sixth joint task force of the european society of cardiology and other societies on cardiovascular disease prevention in clinical practice. Eur Heart J. 2016;37(29):2315-81.

7. Abu-mostafa N, Al-showaikhat F, Al-shubbar F, Al-zawad K, Al- F. Hemodynamic changes following injection of local anesthetics with different concentrations of epinephrine during simple tooth extraction: A prospective randomized clinical trial. J Clin Exp Dent. 2015;7(4):e471.

8. Henrique $\mathrm{H}$, Morais A De, Holanda J. Clinical study of hemodynamic changes comparing $4 \%$ articaine hydrochloride with 1: 100,000 and 1:200,000 epinephrine. Oral Surg Oral Med Oral Pathol Oral Radiol. 2013;116(1):e14-22.

9. Elad S, Admon D, Kedmi M, Naveh E. The cardiovascular effect of local anesthesia with articaine plus 1: 200,000 adrenalin versus lidocaine plus 1: 100,000 adrenalin in medically compromised cardiac patients : a prospective, randomized, double blinded study. Oral Surgery, Oral Med Oral Pathol Oral Radiol Endodontology. 2008;105(6):725-30.

10. Malamed SF. Handbook of local anesthesia. 6th ed. Los Angeles: Elsevier; 2011. 428 p.

11. Becker DE, Reed KL. Local anesthetics : review of pharmacological considerations. Anesth Prog. 2012;59(2):90102.

12. Goodman LS, Gilman A. The pharmacological basis of therapeutics. 12th ed. Brunton LL, editor. New York: Mc Graw-Hill Medical; 2011

13. Sherwood L. Human Physiology: From cells to systems. 7th ed. Belmont: Yolanda Cossio; 2010.

14. Akinmoladun VI, Okoje VN, Akinosun OM, Adisa AO, Uchendu OC. Evaluation of the haemodynamic and metabolic effects of local anaesthetic agent in routine dental extractions. J Maxillofac Oral Surg. 2013;12(4):4248. 